\title{
The Role of Microalgae in the Cultivation of Zooplankton (Daphnia)
}

\author{
S. M. Haydarov ${ }^{1}$, D. A. Mirzayeva ${ }^{2}$, N. A. Khujamshukurov ${ }^{2 *}$, Z. S. Shakirov ${ }^{3}$, \\ D. Kh. Kuchkarova ${ }^{4}$ and Kh. Kh. Abdinazarov
}

${ }^{1}$ Tashkent State Agrarian University; ${ }^{2}$ Tashkent Chemical-Technological Institute, ${ }^{3}$ Institute of Microbiology, Uzbek Academy of Sciences; ${ }^{4}$ Tashkent Architectural-Civil Engineering

Institute; ${ }^{5}$ Kokand State Pedagogical Institute, Kokand, Uzbekistan

*Corresponding author

\section{A B S T R A C T}

\begin{tabular}{l} 
K e y w o r d s \\
Cladocera, \\
Daphnia, Moina, \\
Chlorella, \\
Microalgae, Algae, \\
Zooplankton, Fish \\
feed, Aquaculture \\
Article Info \\
$\begin{array}{l}\text { Accepted: } \\
\text { 26 April } 2020 \\
\text { Available Online: } \\
\text { 10 May } 2020\end{array}$ \\
\hline
\end{tabular}

In this study, the morpho-biological characteristics of the Daphnia magna Straus culture and microalgae of the genera Ankistrodesmus, Botryococcus, Scenedesmus, Chlorococcum and Chlorella were studied. Protein and fat storage of micronutrients was determined. It has also been found that when Daphnia magna cultures are propagated on the basis of micronutrients, their growth rate and biomass production. The results showed that the average growth rate of daphnia on the basis of strains of the genus Chlorella was $1.33 \%$, on the strains of the genus Chlorococcum $-0.74 \%, 55.5 \%$ higher than the chlorella strains $43.1 \%$ higher than the strains of the genus Scenedesmus. This is due to the fact that the cells of the Chlorella strain are thicker and more difficult to break down than other species. The protein and fat storage of the Daphnia magna Straus culture grown on the basis of micronutrients has been studied. According to the results obtained, Daphnia magna Straus, fed on the basis of representatives of the Ankistrodesmus generation from microalgae relative to the control, recorded $28.67 \%$ protein and $3.9 \%$ fat. The Scenedesmus genus has $29.07 \%$ protein, $4.03 \%$ fat, Botryococcus $31.36 \%$ protein, $4.12 \%$ fat, Chlorella $28.60 \%$ protein, $3.64 \%$ fat, Chlorococcum $34.10 \%$ protein and 3 , $84 \%$ fat retention was found. Daphnia species based on Chlorococcum and Botryococcus microalgae have been recommended for breeding and use as a source in feeding small fish fry.

\section{Introduction}

According to statistics, by 2050 , there will be a problem in providing food to more than 9 billion people. According to the FAO (2013), by 2050 , the demand for meat products will increase by $58 \%$ and the demand for dairy products by $70 \%$ compared to 2010 . It is known that animal husbandry is one of the most productive sectors, $35 \%$ of the world's production and $75 \%$ of agricultural production is spent on the development of this industry. It also consumes $8 \%$ of the world's drinking water (including food crops) (Foley et al., 2011).

In addition, the livestock sector emits $14.5 \%$ of all anthropogenic greenhouse gases, which is equivalent to about 7.1 gigatons of $\mathrm{SO}_{2}$ per year (Gerber et al., 2013). Livestock production also requires a significant amount of water (Mekonnen and Hoekstra, 2012). 
As a result, the production of livestock products requires a huge amount of resources, including the production of feed, which is convenient to produce, low cost and rich in all the necessary ingredients, shows that it is one of the most pressing problems. It is also important to meet the demand of people for meat and meat products rich in complete nutrients and nutritious, especially essential for human health, rich in essential amino acids, one of the most active areas in this area is fishing (Agboola et al., 2019).

Significant research is being conducted to further develop the fishing industry and provide the fishing industry with nutritious feed and supplements (Huan Shi et al., 2019), including important research on the production of live feed and their role and importance in nature (Loh Jiun Jan 2011; Herawati et al., 2014a; Herawati et al., 2015b; FitoreKusari et al., 2017). One of the important tasks was to fully provide the fishing industry with live feed and to demonstrate their importance in practical research.

Therefore, the purpose of this study was to analyze the amino acid composition that determines the nutrient content of important zooplankton used as live feed. Zooplankton are one of the important natural sources in the cultivation of fish fry with the storage of crude protein, amino acids, fat kilos, minerals and enzymes.

Of the amino acids, lysine and methionine are especially important in that they are found in very small amounts in other types of feed, that is, in large quantities, and in large quantities in zooplankton. Also, because the composition of zooplankton is also rich in fatty acids, it also plays an important role in the cultivation of fish larvae. While zooplankton contains high levels of eicosapentanoic acid (20: 5-3) and docosahexaenoic acid (22: 6-3) in semi- unsaturated fatty acids, very low levels of linoleic acid (18: 2 juda6) have been reported (Dabrowski and Rusiecki., 1983). In addition, the high content of fatty acids from tarkibida3 to $\overline{0} 6$ in zooplankton further increases the nutritional value of zooplankton (Herawati, 2018).

Zooplankton are also a source of carotene and play an important role in ensuring the color, odor, and smoothness of the surface of the fish (Spenelli., 1979). Live food contains enzymes, including amylase, protease, exonulease, and esterase, which are important in the digestion of fish larvae (Munilla-Moran et al., 1990). The importance of these enzymes is especially great when small fish are given large feed feeds.

The continuous supply of Moina, which is a live feed in fishery water bodies, ensures that fish fry, larvae and mature fish are resistant to external abiotic and biotic factors, including disease resistance, easy digestion and consequently easy weight gain (SipaúbaTavares and Bachion, 2002).

Therefore, Moina is one of the most favorable zooplankton objects in terms of high efficiency, very fast reproduction, resistance to saline environment, very good adaptation to water basin environment. In trout farming, zooplankton are grown in large-scale production facilities, namely Daphnia and Moina (16 Watanabe et al., 1983) has been used effectively in the breeding of fish fry (Tech, 1981).

The role of zooplankton in the development of fish belonging to the genus Rotifer (Brachiomus plicatilis) has been confirmed by Devetter (1998). All species of zooplankton Numerous scientific studies are being carried out in order to increase arni on an industrial basis and to create a continuous supply for the fishing industry (Abdinazarov et al., 2018). In this research, microflora, mostly Chlorella or 
Scenedesmus species, were used to breed zooplankton.

\section{The purpose of the work}

The aim of this study is to study the average size, protein and fat storage of Daphnia magna when used in microalgae as a food source for industrial cultivation.

\section{Materials and Methods}

\section{Research methods (including equipment)}

\section{Objects of research}

The following genera of algae isolated and algologically purified from different regions of Uzbekistan were used: Ankistrodesmus (Ankistrodesmus sp.15., Ankistrodesmus sp.20), Botryococcus (Botryococcus sp. 5., Botryococcus sp. 14), Scenedesmus sp. 1., Scenedesmus sp.7.), Chlorococcum (Chlorococcum sp. 3., Chlorococcum sp. 4.) Chlorella (Chlorella sp. 3., Chlorella sp. 4.). Chu-13 nutrient medium (g/1) was used for growing algae: $\mathrm{KNO}_{3}-0.2, \quad \mathrm{~K}_{2} \mathrm{HPO}_{4}-0.04$, $\mathrm{MgSO}_{4} \times 7 \mathrm{H}_{2} \mathrm{O}-0.1, \quad \mathrm{CaCl}_{2} \times 6 \mathrm{H}_{2} \mathrm{O}-0.08$, iron citrate- 0.01 , lemon acidity-0.1, boron- 0.5 ppm, $\quad \mathrm{MnSO}_{4} \times 7 \mathrm{H}_{2} \mathrm{O} \quad-\quad 0.5 \quad \mathrm{ppm}$, $\mathrm{CuSO}_{4} \times 5 \mathrm{H}_{2} \mathrm{O}-0.02 \mathrm{ppm}, \mathrm{CoCl}_{2} \times 2 \mathrm{H}_{2} \mathrm{O}-0.02$ ppm, $\mathrm{Na}_{2} \mathrm{MoO}_{4} \times 2 \mathrm{H}_{2} \mathrm{O}-0.02$ ppm, pH 7.5 (Safarov et al., 2019). In the cultivation of algae, $\mathrm{SO}_{2}$, light and air were given in standard form (Mata et al., 2010). Temperature $27-30^{\circ} \mathrm{C}$. Standard methods were used to determine the microscopy of algae and their morpho-cultural properties (Shakirov et al., 2014). It was used in the feeding of daphnia with micronutrients in the amount of $1 \mathrm{ml} / 1$ or 1000 million cells $/ \mathrm{ml}$. The number of cells in Goryaeva's cell was calculated using standard methods.

Zooplankton was used as an object from Daphnia magna culture isolated from artificial (temporary) reservoirs in Andijan region and stored as a collection zooplankton in the scientific laboratory "Biotechnology" of the Tashkent Institute of Chemical Technology (Classification: Animalia $\rightarrow$ Arthropoda von Siebold et Stannius, 1845 Latreille, $1817 \rightarrow$ Cladocera $\rightarrow$ Daphniidae $\rightarrow$ Daphnia $\rightarrow$ Daphnia magna Straus (22 Abdinazarov et al., 2019). A standard ADaM nutrient medium was used to keep daphnia alive (23 B. Klüttgen, 1994). In determining the nutritional value of microflora. Organic nutrient medium (20\% cattle manure) was used as a control medium for growing. The nutrient medium was enriched with daphnia twice a week with fresh feed. Temperature $20-22^{\circ} \mathrm{C}$.

Lowry's method for determining the amount of protein in research objects (Lowry, 1951) used the standard method to determine the amount of fat (Rajasri et al., 2012). The calculation of statistical error, mean, reliability intervals and standard deviations to the experimental data was performed using the computer program STATISTICA 6.0 and standard methods. The statistical significance of the results was determined using the Student t-criterion.

\section{Results and Discussion}

It is known that in world practice it is widely used in the production of protein biomass from Chlorella, Ankistrodesmus and Scenedesmus microalgae, as well as in the cultivation of zooplankton (Daphnia,Moina) under artificially controlled conditions. From zooplankton, the culture of Scenedesmus quadricauda is widely used in the reproduction of species such as Daphnia magna, pulex and longispina (Ranta et al., 1993). Based on the studies, the morphological and biological properties and average sizes of algologically purified microflora were determined depending on the 
generation (Figure 1). During the study, the morpho-biological properties of Daphnia magna, the object of study, were studied using the ADaM nutrient medium (Fig. 1).

The standard temperature was set at $20^{\circ} \mathrm{C}$. The studies were followed for six months to determine the morpho-biological properties and average size of Daphnia magna in the $\mathrm{ADaM}$ nutrient medium. According to the results obtained, the morpho-biological properties of Daphnia magna do not differ significantly from the properties recorded in scientific sources. It was noted that the life expectancy when growing ADaM nutrient medium was 62 days, with an average length of $1.25-1.6 \mathrm{~mm}$. These indicators, together with a standard nutrient medium and yeastbased feed, were used as a control option for further research. As a result of the study, it was noted that the output of dry matter from microalgae relative to wet biomass varies on average from 22.99 to $28.84 \%$ (Figure 2).

In particular, the strains of the Ankistrodesmus generation produced an average of 3.24-3.42 grams of dry biomass from 11.36-12.62 grams of wet biomass, which was found to be $27.10-28.52 \%$ of the total wet biomass. In Scenedesmus strains, $10.66-11.44 \mathrm{~g} / \mathrm{l}$ of wet biomass accounted for 2.48-3.08 g/l of dry biomass, or 23.26-26$92 \%$ of the total humus biomass. Although similar results were obtained for Chlorella and Chlorococcum strains, it was noted that this figure was relatively low in Botryococcus strains. It was observed that Botryococcus strains accounted for 8.62-9-22 g/l of wet biomass, 2.04-2.12 g/l of dry biomass, or $22.99-23-67 \%$ of the total wet biomass.

Subsequent research has studied the protein and fat storage of micronutrients selected as an object (Figure 3). As can be seen from Figure 3, the protein and fat storage of micronutrients in the Chu-13 nutrient medium are drastically different from each other. In particular, microalgae belonging to the genus Ankistrodesmus contain $43.2-46.4 \%$ protein and 27.4-32.2\% fat (Ankistrodesmus sp.20; Ankistrodesmus sp.15). In the same nutrient medium, micronutrients belonging to the genus Scenedesmus can be seen to store up to 48.8-52.8\% protein and 27.4-28.6\% fat, respectively (Scenedesmus sp.7. and Scenedesmus sp.1).

According to the results of the study, representatives of the genus Botryococcus were recorded as a microflora offspring that retained relatively small amounts of protein (46.2-46.8\%) and fat (26.2-26.4\%).

Studies have shown that members of the Chlorococcum and Chlorella lineages have high protein retention (46.4-48.8\%) but very low fat retention (15.6-18.4\%) compared to all micronutrient generations studied. In scientific sources, $46.5 \%$ of the strain Chlorococcum macrostigmatum UT4 and $35.4 \%$ of the strain Chlorella sp. 2 were studied for fat synthesis (27 Safarov, 2020). This can be explained by the control of temperature, $\mathrm{SO}_{2}$ and light levels under growing conditions, and the fact that the study focused on fat synthesis.

Subsequent studies have determined the growth rate of Daphnia magna Straus, depending on the composition of the nutrient medium (Fig. 4). It was noted that the results obtained varied depending on the generation of micronutrients and their nutritional value (based on the amount of protein and fat).

In particular, the growth rate of daphnia depending on the composition of the nutrient medium, relative to the controlled nutrient medium (lake water $+20 \%$ cattle manure) Ankystrodesmus - 0.4969, Scenedesmus 0.4181, Botryococcus - 0.5644, Chlorella 0.3267 and Chlorococcum - 0.7357 percent. 
In contrast to scientific sources, the average growth rate of daphnia based on the strains of the genus Chlorella was $1.3267 \%$, while the strains of the genus Chlorococcum - $0.7357 \%$, $55.5 \%$ higher than the strains of the genus Scenedesmus $-43.1 \%$ higher than the strains of the genus Chlorella found to be this can be explained by the fact that the cells of the strains of the genus Chlorella are thicker and more difficult to break down than other species. Although the cell structure and thickness of Scenedesmus strains do not differ significantly from those of Chlorococcum, the difference in growth rate is due to the relative size of the cell of Chlorococcum strains, protein content less than that of Scenedesmus strains $(47.8-48.2 \%)$, low fat content (16.8$48.2 \%$ ). 8-18.4\%), which may have led to faster assimilation of nutrient proteins.

Subsequent studies have studied the protein and fat storage of the grown Daphnia magna Straus relative to dry matter in a nutrient medium prepared on the basis of algae generations (Figure 5).

According to the results obtained, Daphnia magna Straus, fed on the basis of representatives of the Ankistrodesmus generation from microalgae relative to the control, recorded $28.67 \%$ protein and $3.9 \%$ fat. The Scenedesmus genus has $29.07 \%$ protein, $4.03 \%$ fat, Botryococcus $31.36 \%$ protein, $4.12 \%$ fat, Chlorella $28.60 \%$ protein, $3.64 \%$ fat, Chlorococcum $34.10 \%$ protein and $3,84 \%$ fat retention was found.

When the results were analyzed, it was found that Daphnia magna (31.36\%) fed with Botryococcus offspring synthesized $2.76 \%$ more protein and $0.48 \%$ more fat storage than Chlorella offspring. Similar results were observed for Daphnia magna fed Chlorococcum, which synthesized $5.03 \%$ more protein and $0.19 \%$ more fat synthesized than Daphnia magna fed Scenedesmus. It was also noted that protein synthesis when fed Daphnia magna with Chlorococcum was $5.43 \%$ more protein than Ankistrodesmus, $5.5 \%$ more than Chlorella, and $5.03 \%$ more than Scenedesmus. Daphnia magna was reported to synthesize $2.69 \%$ more protein than Ankistrodesmus, $2.29 \%$ more than Scenedesmus, and $2.76 \%$ more than Chlorella when fed to members of the Botryococcus genus. Daphnia magna fed with representatives of the botryococcus genus was found to synthesize $0.22 \%$ more fat than Ankistrodesmus, $\quad 0.28 \%$ more than Chlorococcum, and $0.48 \%$ more than Chlorella. Therefore, it is advisable to use zooplankton from the representatives of Chlorococcum and Botryococcus genera in fisheries, namely Daphnia species, as a source of reproduction and feeding of small fish fry.

The world food market for aquaculture is estimated at $\$ 57.7$ billion (2012), and its volume is projected to reach $\$ 122.6$ billion by 2019 , with an annual growth rate of $11.4 \%$. However, world production did not reach this figure. The demand for product types in the world market for aquaculture facilities also varies. In particular, food products are sold on the world market for carp (40\%), tilapia (20\%), crustaceans and salmon (about 20\%), as well as mollusks, crucian carp and others (Feed International's World Feed Panorama., 2016). According to experts from the research organization Transparency Market Research, by 2021, food products for carp and crustaceans will occupy a major share of the world market. Food production for mollusks and salmon is also expected to grow rapidly. In addition, due to its geographical location, the Asia-Pacific region is expected to control $65 \%$ of the world market and the rapid development of aquaculture in them. Europe may rise to second place in terms of food production for aquaculture (Aqua Feed Market, 2013-2019). 


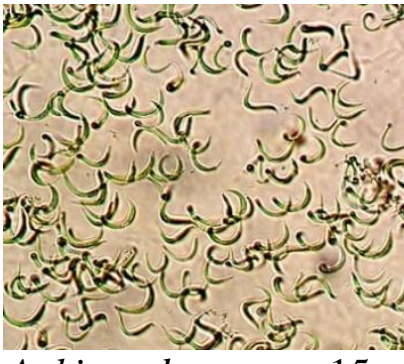

Ankistrodesmus sp. 15.

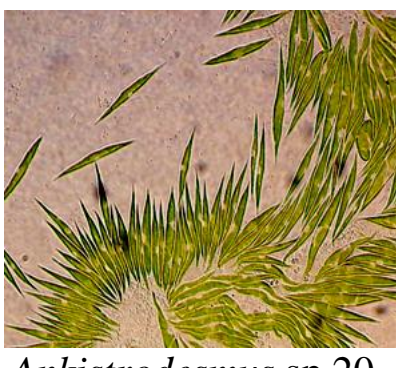

Ankistrodesmus sp. 20

Ankistrodesmus genus: cells elongated, curved, elongated filamentous, spiral. Propagated by autospores, their average size is 4-20 microns.

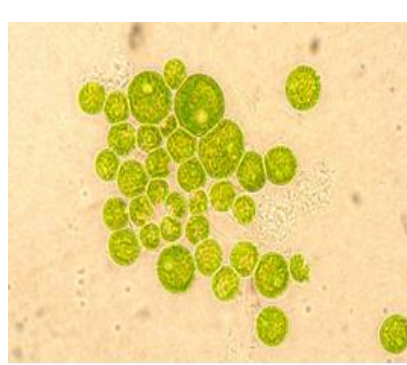

Botryococcus sp.5.

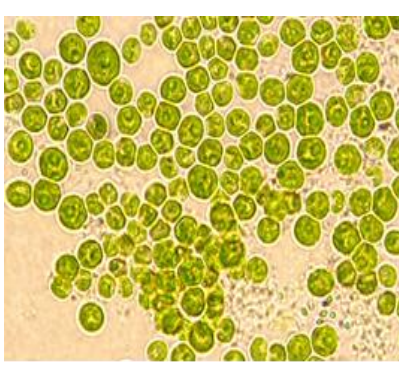

Botryococcus sp. 4.
Botryococcus genus: the shape of the cells is round, noxious, the cell shell is thin, smooth, colorless. Propagated by autospores, the average size of the cells is $3-15 \mu \mathrm{m}$.

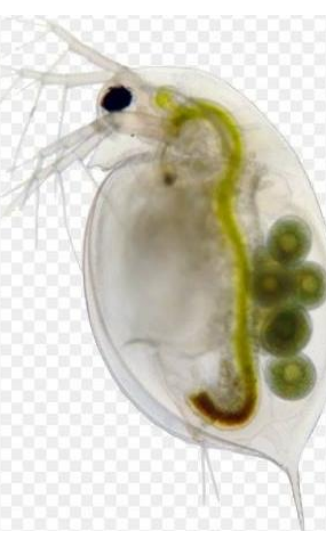

Daphnia magna Straus: females $1.2-1.6 \mathrm{~mm}$ long, males $1.2-1.8 \mathrm{~mm}$. Matures in $4-14$ days. Females give birth to 20 male daphnia every 1214 days. Female burials occur only in summer.

Throughout the summer they reproduce parthenogenetically.

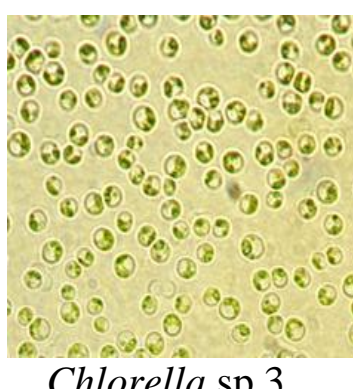

Chlorella sp.3.

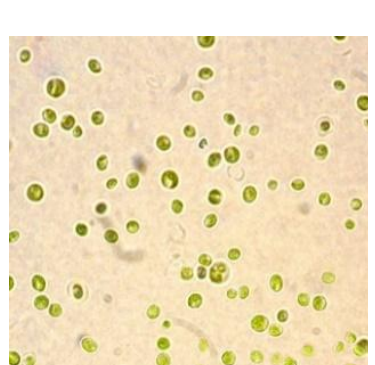

Chlorella sp.4

Chlorella genus: cells are spherical, round, oval, elliptical, short cylindrical, propagated by autospores. Their average size was noted to be $1.5-13 \mu \mathrm{m}$.

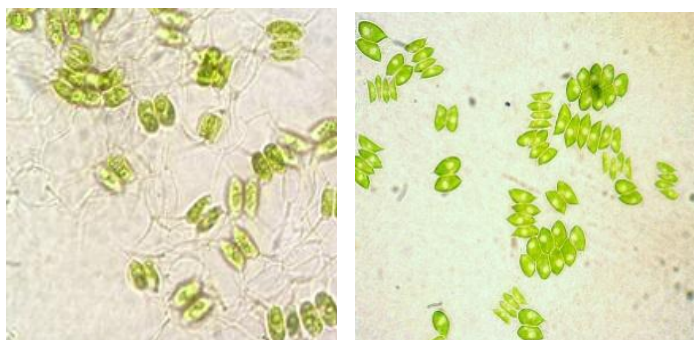

Scenedesmus sp.7. Scenedesmus sp.1.

Scenedesmus genus: Its cells are elongated, cylindrical, oval, avoid and elliptical in shape. The average size is 15-20 microns and propagated by autospores.

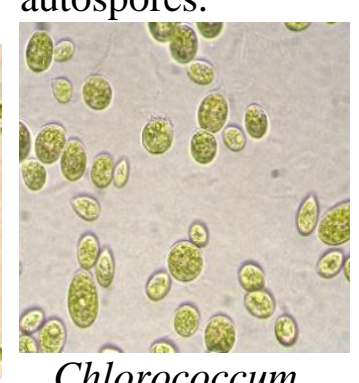

Chlorococcum

sp.4.

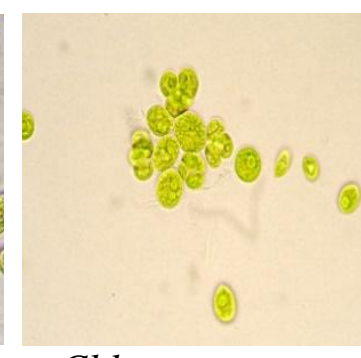

Chlorococcum

sp.3.
Chlorococcum genus: The cells are spherical, oval and oblong - circular. They reproduce using zoospores the average resolution is 4-25 microns the color is green, blue and brown in appearance.

Fig.1.A brief morphological and biological description of the descendants of Daphnia magna and microflora (Daphnia magna picture taken from the internet) 


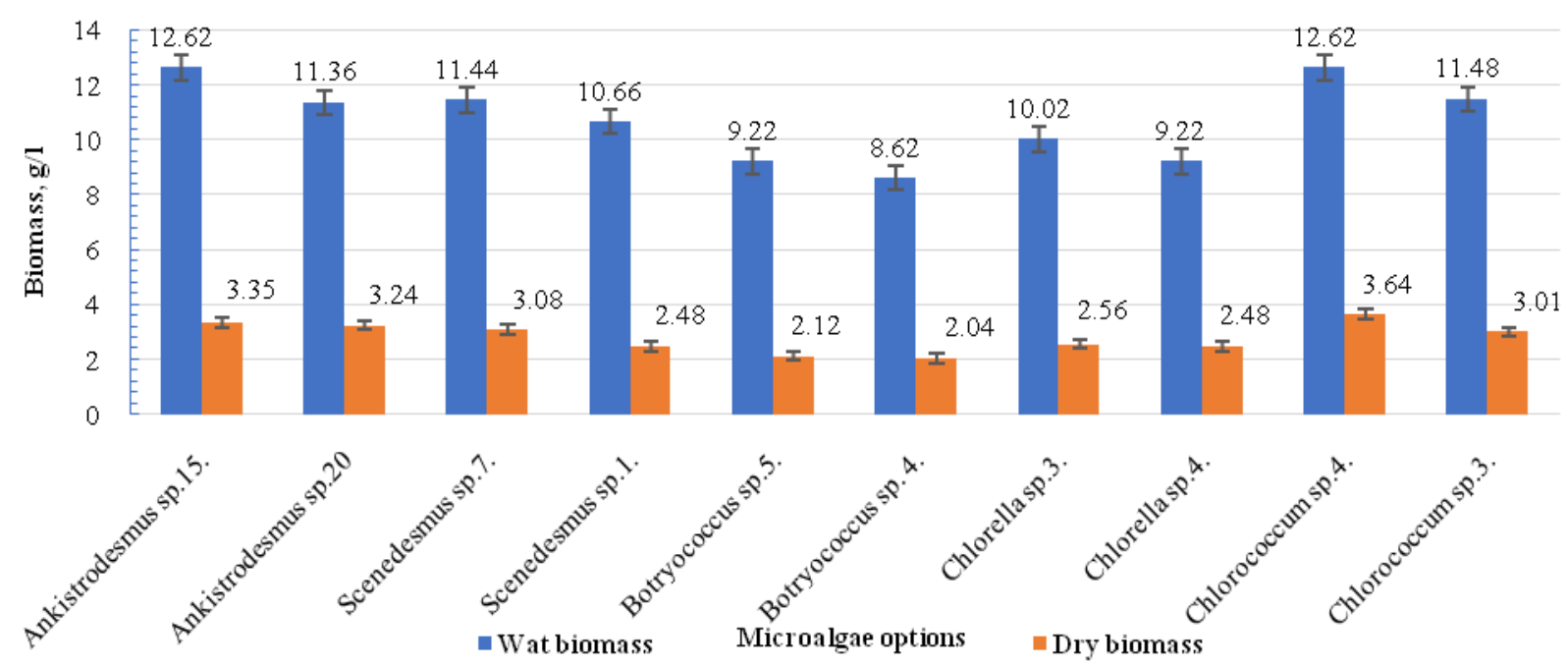

Figure.2 Biomass generation of microalgae
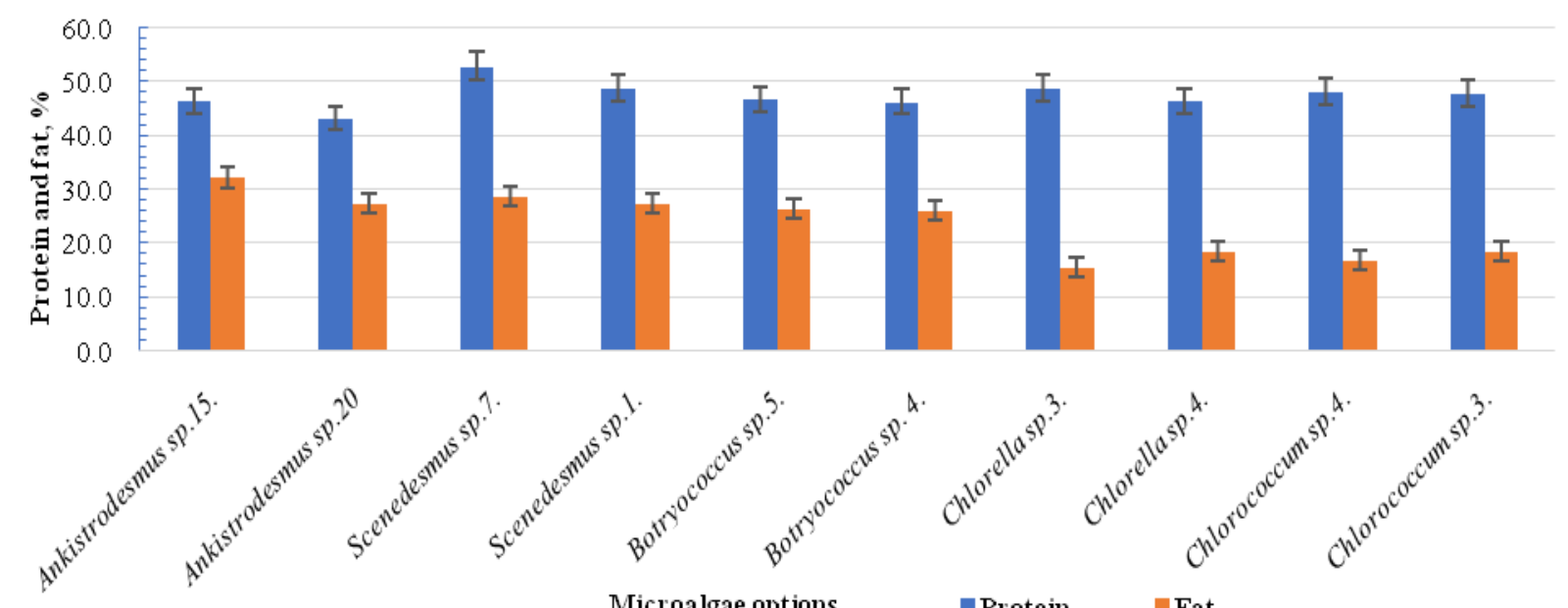

Microalgae options

- Protein Fat

Figure.3 Protein and fat storage of micronutrients (in\% to dry matter)

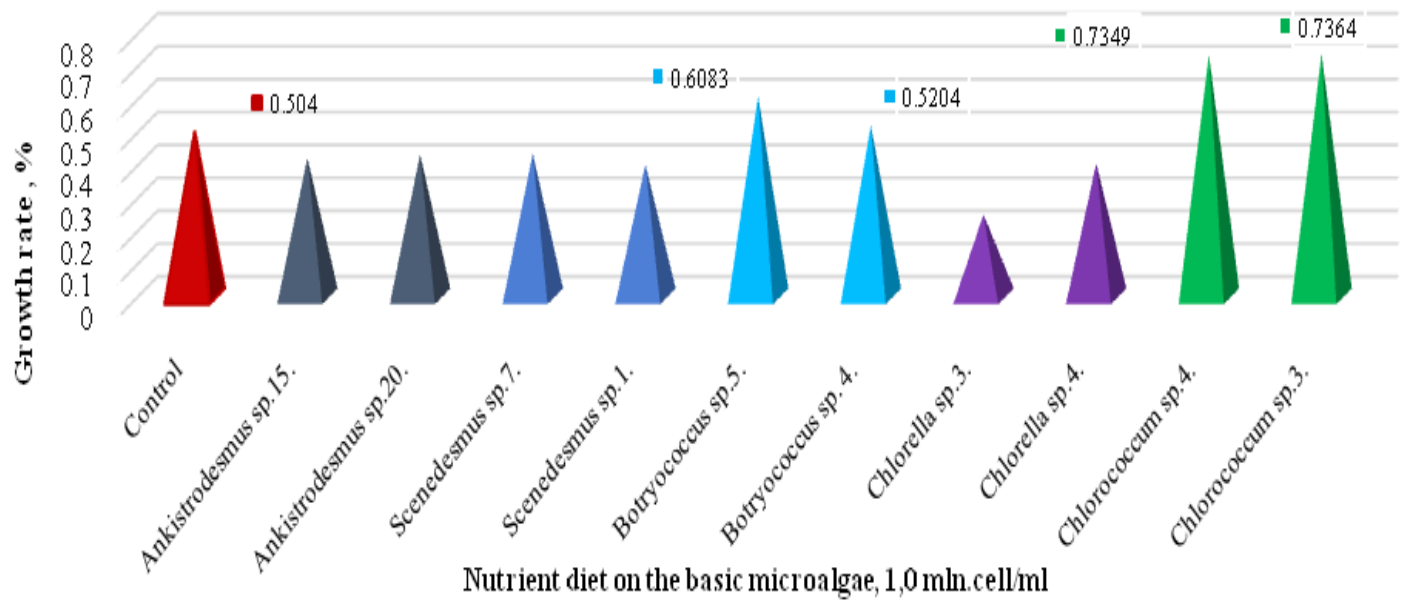

Figure.4 Influence of microflora on the growth rate of Daphnia magna Straus 
According to experts, radical changes in the food industry for aquaculture are expected. There are many factors of drastic change, which can be summarized as follows: feed for aquaculture (soy, wheat and corn, fish-based feed), as well as traditional technology based on the leading trend of "feeding fish with fish" and its current state does not meet the requirements of long-term sustainable development of the world fishing industry (Khujamshukurov et al., 2016).

Therefore, in the world fishing industry, the greatest attention is paid to the production of natural (live) feed and its effective use in practice. Therefore, the results of this study show that the effective organization of industrial cultivation of Daphnia magna, which belongs to the group of zooplankton of the natural food base, and the use of microalgae Chlorococcum and Botryococcus in the continuous formation of its food base is promising.

\section{Acknowledgements}

This research was carried out within the framework of the innovative project I-OT2019-21 of the Ministry of Innovation Development of the Republic of Uzbekistan. We would like to thank Professor A. Kuzmetov of Tashkent State Agrarian University and the National University of Uzbekistan, as well as the staff of the Tashkent Institute of Chemical Technology, Biotechnology Research Laboratory (Prof. Khujamshukurov NA) for their close assistance in carrying out the research.

\section{References}

Abdinazarov H.H., Kuzmetov A.R., Khaydarov S.M., Nomonov J.N. 2018. Qualitative and quantitative development of zooplankton organisms in Fergana valley water reservoir. JNAS.7-4/44-47.

Abdinazarov X.X., Madumarov M.J., Haydarov S.M. 2019. Zooplankton of Sarikamish Lake (Uzbekistan). Open Access Library Journal. Vol.6, e.5288, pp.1-8. doi:10.4236/oalib.1105288.

Agboola JO, Yossa R. and Verreth J. 2019. Assessment of existing and potential feed resources for improving aquaculture production in selected Asian and African countries, Penang, Malaysia: CGIAR Research Program on Fish Agri-Food Systems, Program Report: FISH-2019-03.

Aqua Feed Market: Global Industry Analysis, Size, Share, Growth, Trends and Forecast, 2013-2019: Transparency Market Research. URL:http://www.transparencymarketr esearch.com/aqua-feed-market.html.

Dabrowski, K., Ruseicki, M. (1983): Content of total and free amino acids in zooplanktonic food of fish larvae. Aquaculture, 30, 31-42.

FAO.2013. Food wastage footprint: impact on natural resources. Summary report. Food and Agriculture Organization of the United Nationa, Rome. http://www.fao.org/docrep/018/i3347e /i3347e.pdf

Feed International's World Feed Panorama: Lack of Quality Feeds Slows Russia's Aquaculture Sector. URL: http://www.fi-digital.com/201604/\#/4.

Fitore Kusari., Alan M. O’Dohert., Nikolas J.Hodges., Marcin W. Wojewodzic. 2017. Bi-directional effects of vitamin $\mathrm{B}_{12}$ and methotrexate on Daphnia magna fitness and genomic methylation. Scientific Reports. 7:11872. doi:10,1038/s41598-01712148-2.

Foley Jonathan A., Navin Ramankutty. Kate A. Brauman. Emily S. Cassidy. James S. Gerber. Matt Johnston. Nathaniel D. Mueller. Christine O'Connell. 
Deepak K. Ray. Paul C. West. Christian Balzer. Elena M. Bennett. Stephen R. Carpenter. Jason Hill. Chad Monfreda. Stephen Polasky. Johan Rockstrom. John Sheehan. Stefan Siebert. David Tilman \& David P.M.Zaks. 2011. Solutions for a cultivated planet//Nature. Vol.478. Pp.337-342. doi:10.1038/nature10452.

Gerber P.J., Steinfeld H., Henderson B., Mottet A., Opio C., Dijkman J., Falcucci A., Tempio G. 2013. Tackling climate change through livestock - A global assessment of emissions and mitigation opportunities, Food and Agriculture Organization of the United Nations (FAO). Rome. Pp.139.

Herawati VE, Agus M. 2014a. Analysis growth and survival of catfish larvae feedDaphnia sp, in mass culture using fermented organic fertilizer. J.Sci Tech. 26:1-11.

Herawati VE., Pinandoyo JH., Radjasa JH. 2015b. Growth and Survival Rate of Tilapia (Oreochromis niloticus) Larvae Fed by Daphnia magna Cultured With Organic Fertilizer Resulted From Probiotic Bacteria Fermentation. Hayati Journal of Biosciences 22(2015). Pp.169-173. http://dx.doi.org/10.1016/j.hjb.2015.0 8.001 .

Herawati VE.,Pinandoyo., Hutabarat J., Karnaradjasa O. 2018. The effect of nutrient content and production of Daphnia magna mass culturedusing various wastes processed with different fermentation time, AACL Bioflux, Volume 11. Issue 4. Pp. 1289-1299. http://www.bioflux.com.ro/aacl.

Huan Shi. Jong Keun Kim. In Ho Kim. Eff ects of dietary L-arginine on growth performance, nutrient digestibility, gas emission, and meat quality in finishing pigs, Animal Feed Science and Technology, 253 (2019)93-100. doi:https://doi.org/10.1016/j.anifeedsci .2019,05.007.

Khujamshukurov N.A., Nurmuxamedova V.Z. 2016. Production feed: modern trend and development aspect. Scientific overview. J. Zooveterinary. № 8 (105): 34-37.

KlüttgenB. 1994. ADaM, an artificial freshwater for the culture of zooplankton /B. Klüttgen, U. Dülmer, M. Engels, H.T. Ratte// Water Research. V.28.Pp.743-746.

Loh Jiun Yan. 2011. Fatty acid enrichment and potential food source for Moina macrocopa cultivation. Master of Science at Universiti Tunku Abdul Rahman. Pp.187.

Lowry, 0. H., N. J. Rosebrough, A. L. Farr, and R. J. Randall. (1951). Protein measurement with the Folin phenol reagent. J.Biol. Chem, 193: 265-275.

Mata T.M., Martins A.A and Caetano N.S. 2010. Microalgae for biodiesel production and other applications, Renew. Sust. Energ. Rev., 14(1), 21732.

Mekonnen M.M., Hoekstra A.Y.2012. A Global Assessment of the Water Footprint of Farm Animal Products// Ecosystems. 15:401-415, doi:10.1007/s10021-011-9517-8.

Rajasri Y, Ramgopal SR, Rao CS. Lipid accumulation studies In Chlorella pyrenoidosa using customized photobioreactor- effect of nitrogen source, light intensity and mode of operation. J Eng Res. Appl. 2012; 2: 2446-2453.

Ranta E., Bengtsson J., McManus J. 1993. Growth, size and shape of Daphnia longispina, D. magna and D.pulex. Ann.Zool. Fennici. 30: 299-311.

Safarov I.V. 2020. Highly productive lipid- 
producing microalgae of Uzbekistan and regulation of the biosynthesis of oils for obtaining biodiesel. PhD thesis in microbiology. Uzbekistan. P.136.

Safarov I.V., Abdullaev A.K.,
Khujamshukurov N.A., Shakirov Z.S. 2019. Influence of Temperature and $\mathrm{CO}_{2}$ on the Growth and Accumulation Oil of Microalgae. Emerging Issues in Science and Technology Vol. 1. Pp. 93-101.

Samuel Avengbe Okunsebor, 2014, Culture of zooplankton (Brachionus calyciflorus, Moinamicrura and Daphnia pulex) as live food for Heterobranchus bidorsalis hatchlings. $\mathrm{PhD}$ thesis in applied hydrobiology and fisheries of theuniversity of Jos. P.189.

Shakirov ZS., Safarov IV.,KadirovaGKh., Khujamshukurov NA. 2014. Isolation and identification of lipid-producing microalgae of Uzbekistan. Environmental Science. Vol. 9: 405409.

Watanabe T., Takashima F., Kobayashi I., Utsue O., Ogino C. 1975. Effect of dietary methyl linoleate and linolenate on growth of carp. Bull. Jap. Soc. Fisheries, 41, 257-262.

\section{How to cite this article:}

Haydarov, S. M., D. A. Mirzayeva, N. A. Khujamshukurov, Z. S. Shakirov, D. Kh. Kuchkarova and Abdinazarov, Kh. Kh. 2020. The Role of Microalgae in the Cultivation of Zooplankton (Daphnia). Int.J.Curr.Microbiol.App.Sci. 9(05): 3356-3365.

doi: https://doi.org/10.20546/ijcmas.2020.905.399 